De Jure: Jurnal Hukum dan Syar'iah

Vol. 11, No. 2, 2019, h. 128-142

ISSN (Print): 2085-1618, ISSN (Online): 2528-1658

DOI: http://dx.doi.org/10.18860/j-fsh.v11i2.6580

Available online at http://ejournal.uin-malang.ac.id/index.php/syariah

\title{
Model Small Claim Court Sebagai Alternatif Penyelesaian Perkara di Pengadilan Agama Perspektif Teori Keadilan John Rawls
}

\author{
Erfaniah Zuhriah \\ UIN Maulana Malik Ibrahim Malang, Indonesia \\ erfaniah@yahoo.com \\ Miftahuddin Azmi \\ UIN Maulana Malik Ibrahim Malang, Indonesia
}

\begin{abstract}
:
Small Claim Court is one of the efforts of the Supreme Court of the Republic of Indonesia to reduce the accumulation of cases in court. This article seeks to describe the small claim court model as an alternative to the settlement of cases in the Religious Courts to realize the principle of quick, simple, and low-cost perspective of John Rawls's theory of justice. This article originates from doctrinal law research from the statutory approach, the comparative approach, the conceptual approach. The results of this study indicate that a small claim court can reduce the accumulation of cases in a religious court. The application must meet two criteria; namely, the disputed nominal does not exceed 200 million and does not require complicated verification. As regulated in the Republic of Indonesia Supreme Court Regulation No. 2 of 2015.

Small Claim Court merupakan salah satu upaya Mahkamah Agung Republik Indonesia untuk mengurangi penumpukan perkara di pengadilan. Artikel ini berupaya mendeskripsikan model small claim court sebagai alternatif penyelesaian perkara di Pengadilan Agama untuk mewujudkan asas cepat sederhana dan biaya ringan perspektif teori keadilan John Rawls. Artikel ini berasal penelitian hukum doktrinasi dengan dari pendekatan perundang-undangan (statute approach), pendekatan perbandingan (comparative approach), pendekatan konseptual (conceptual approach). Hasil penelitian ini menunjukkan bahwa small claim court dapat mengurangi penumpukan perkara di pengadilan agama. Penerapannya harus memenuhi dua kriteria, yaitu nominal yang disengketakan tidak melebihi angka 200 juta dan tidak memerlukan pembuktian yang rumit. Sebagaimana diatur dalam Peraturan Mahkamah Agung Republik Indonesia Nomor 2 Tahun 2015.
\end{abstract}

Kata Kunci: small claim court; pengadilan agama; keadilan.

\section{Pendahuluan}

Peradilan Agama dewasa ini mengalami perkembangan yang sangat pesat. Hal ini terlihat jelas dari adanya penambahan kewenangan dan ruang lingkup kekuasaan yang dimiliki oleh Peradilan Agama. Peradilan Agama adalah salah satu dari pelaksana kekuasaan kehakiman bagi masyarakat pencari keadilan yang beragama Islam serta 
menyelesaikan perkara tertentu sebagaimana tertuang di dalam Pasal 2 Undang-Undang Nomor 3 Tahun 2006 tentang Perubahan Undang-Undang Nomor 7 Tahun 1989 tentang Peradilan Agama. ${ }^{1}$ Kemudian ketentuan dalam Pasal 2 ayat (4) Undang-Undang Nomor 48 Tahun 2009 tentang Kekuasaan Kehakiman dan Pasal 57 ayat (3) Undang- Undang Nomor 7 Tahun 1989 menyatakan bahwa peradilan diselenggarakan dengan asas sederhana, cepat dan biaya ringan. Hal ini berarti Peradilan Agama dalam menyidangkan dan memutus sebuah perkara berdasarkan kewenangan yang dimilikinya haruslah secepat mungkin, tidak rumit, dengan biaya yang mudah dijangkau. ${ }^{2}$

Jika ditinjau dari sifat perkara yang masuk, ada 2 (dua) jenis perkara yang masuk ke Peradilan Agama yaitu: perkara gugatan (contentius) dan perkara permohonan (voluntair). Perkara gugatan (contentius) adalah perkara yang diajukan ke pengadilan dan di dalamnya mengandung sengketa antara dua pihak. Sementara perkara voluntair adalah permohonan bersifat sepihak dan permintaan pada putusan bersifat deklarator. ${ }^{3}$ Proses pengajuan perkara gugatan ataupun permohonan ke pengadilan, baik dalam HIR dan RBg tidak membedakan proses pengajuaannya. Bentuk gugatan atau permohonan sebagaimana ketentuan Pasal 120 HIR atau Pasal 144 ayat (1) RBg dibagi menjadi dua, yaitu bentuk tertulis dan tidak tertulis atau lisan. Kemudian pasal 145 dan pasal 718 Rbg, pasal 121 dan pasal 390 HIR menjelaskan bahwa harus dilakukan dengan surat panggilan resmi.

Berdasarkan penjelasan tata cara dan syarat pengajuan perkara ke pengadilan Agama di atas, sudah jelas bahwa ketentuan hukum perundang-undangan (baik HIR dan $\mathrm{RBg}$ ) tidak membedakan proses hukum acara antara perkara contentius (gugatan) maupun perkara voluntair (permohonan). Padahal perkara ini semua pada dasarnya sangat berbeda dimana faktor adanya sengketa yang membedakannya. Begitu juga ketentuan hukum acara di pengadilan agama tidak membedakan keduanya. Tidak adanya pengklasifikasian atas tingkat kesulitan dan proses penyelesaian perkara berakibat pada tidak terpenuhinya asas peradilan yang dilaksanakan dengan sederana, cepat dan biaya ringan. Hal ini terbukti dari tidak dibedakannya jenis dan tingkatan kesulitan perkara yang masuk ke Pengadilan Agama, sehingga terjadi penumpukan perkara di Peradilan Agama. Laporan tahunan Mahkamah Agung Tahun 2018 menyebutkan bahwa beban kinerja pengadilan agama se-Indonesia mencapai 630.049 kasus, dengan rincian 528.514 perkara gugatan dan 101.535 perkara permohonan. Dari jumlah ini perkara yang diputus mencapai 549.217 perkara dan masih menyisakan 72.600 perkara. ${ }^{4}$ Data ini menunjukkan bahwa masih ada perkara yang belum berhasil diputus hingga masuk tahun 2019. Padahal secara umum, pengadilan telah menerapkan cepat, sederhana dan biaya ringan.

Penyelesaian perkara yang diajukan ke peradilan agama membutuhkan waktu relatif lama menjadi salah satu sebab terjadinya penumpukan perkara. Pengadilan agama membutuhkan waktu minimal 27,8 hari untuk menyelesaikan perkara dari penerimaan

\footnotetext{
${ }^{1}$ Andi Intan Cahyani, "Peradilan Agama Sebagai Penegak Hukum Islam Di Indonesia," Jurnal Al-Qadau: Peradilan Dan Hukum Keluarga Islam 6, no. 1 (30 Juni 2019): 129, https://doi.org/10.24252/alqadau.v6i1.9483.

${ }^{2}$ Mizaj Iskandar dan Liza Agustina, "Penerapan Asas Peradilan Sederhana, Cepat dan Biaya Ringan dalam Kumulasi Cerai Gugat dan Harta Bersama di Mahkamah Syar'iyah Banda Aceh," SAMARAH: Jurnal Hukum Keluarga dan Hukum Islam 3, no. 1 (9 Agustus 2019): 242, https://doi.org/10.22373/sjhk.v3i1.4403.

${ }^{3}$ Yahya Harahap, Kedudukan Kewenangan Dan Acara Peradilan Agama Berdasarkan Undang-Undang No. 7 Tahun 1989 (Jakarta: PT. Garuda Metropolitan Press, 1993), 198.

${ }^{4}$ Mahkamah Agung RI, Laporan Tahunan Mahkamah Agung Republik Indonesia Tahun 2018: Era Baru Peradilan Modern Berbasis Teknologi Informasi (Jakarta: Mahkamah Agung, 2019), 114.
} 
perkara hingga putusan. ${ }^{5}$ selain itu, keterbatasan sumber daya hakim peradilan agama, para pihak yang berperkara, mediasi yang tidak berjalan maksimal, tingkat pendidikan, disparitas pemahaman tentang administrasi perkara turut menjadi faktor penyebab terjadinya penumpukan perkara di pengadilan agama. ${ }^{6}$ Sebagai upaya mengurai persoalan di atas, Mahkamah Agung melakukan beberapa tindakan seperti menyeimbangkan rasio perkara dengan jumlah hakim hingga mengeluarkan kebijakan tentang small claim court. Melalui Peraturan Mahkamah Agung Nomor 2 Tahun 2015, ${ }^{7}$ Mahkamah Agung memberikan regulasi tentang tata cara pengajuan gugatan sederhana atau small claim court di pengadilan, baik pengadilan negeri maupun pengadilan agama.

Beberapa penelitian yang berkaitan dengan small claim court antara lain dilakukan oleh Yulin Fu. Ia membagi perkara yang bisa diselesaikan dengan small claim adalah pertama, perkaranya jelas, hak dan kewajibannya tidak ambigu. Kedua, pengajuan perkara yang telah terjadi konsensus antara pihak yang berperkara. Ketiga, perkara "kecil" misalkan perkara yang sudah jelas dasar hukumnya dan obyek perkara kurang dari 30\% dari obyek sengketa. ${ }^{8}$ Penelitian tentang Small Claim juga dilakukan oleh Nikola Bodiorga, ia berargumen bahwa nilai sengketa yang kategori small claim court adalah sengketa yang tidak lebih dari tiga ribu euro sebagaimana terdapat dalam UndangUndang Rakyat Serbia Tahun 2011. ${ }^{9}$

Lebih lanjut, Yusi Amdani menawarkan restorative justice dalam tindak pidana yang dilakukan oleh anak-anak. Konsep restorative justice lebih menekankan penyelesaian pidana anak dengan rehabilitasi baik dalam hukum Islam maupun hukum adat Aceh, bukan pembalasan. Akan tetapi hal demikian hanya bisa dilakukan terhadap kasus-kasus tertentu. ${ }^{10}$ Penelitian tentang small claim court juga dilakukan oleh Efa Laela Fakhriah, ia menyatakan bahwa penyelesaian sengketa di luar pengadilan (non litigasi) seringkali tidak memiliki daya paksa dan tidak diindahkan, maka diperlukan small claim court untuk menghindari hal-hal tersebut. ${ }^{11}$ Sementara itu Septi Wulan Sari juga mengupas tentang small claim court yang difokuskan di wilayah Tulungagung. Dalam penelitiannya menyimpulkan bahwa prosedur small claim court memudahkan masyarakat dalam berperkara di peradilan. Selain itu perkara yang masuk kategori small claim court di wilayah hukum Kabupaten Tulungagung termasuk perkara kelas "teri" dan tidak cenderung rumit. ${ }^{12}$

\footnotetext{
5 Muharrom Ainul Yaqin, "Konsep Small Claim Procedure Untuk Menyelesaikan Perkara Perdata Permohonan (Volunter) Di Pengadilan Agama," JURISDICTIE 6, no. 1 (2015): 38, https://doi.org/10.18860/j.v6i1.4088.

${ }^{6}$ Malik Ibrahim, "Tunggakan Perkara Di Lingkungan Peradilan Agama Dan Upaya Penanggulangannya," Aplikasia: Jurnal Aplikasi Ilmu-Ilmu Agama 18, no. 1 (30 Januari 2018): 37-41.

${ }^{7}$ Anita Afriana dan Isis Ikhwansyah, "Questioning the Small-Claims Court in Indonesia in the Framework of National Civil Procedural Law Reform," Jurnal Dinamika Hukum 16, no. 3 (2016): 269, https://doi.org/10.20884/1.jdh.2016.16.3.580.

${ }^{8}$ Yulin Fu, Small Claim and Summary Procedure In China, Brics Law Journal 1 (2014), no. 1 (2014): 67, https://doi.org/10.21684/2412-2343-2014-1-1-67-81.

${ }^{9}$ Nikola Bodiroga, Some problems concerning the application of special procedural rules for small claims litigations, Zbornik radova Pravnog fakulteta, Novi Sad 49, no. 2 (2015): 653, https://doi.org/10.5937/zrpfns49-9137.

${ }^{10}$ Yusi Amdani, Konsep Restorative Justice Dalam Penyelesaian Perkara Tindak Pidana Pencurian Oleh Anak Berbasis Hukum Islam Dan Adat Aceh, al- 'adalah XIII, no. 1 (2016): 61.

11 Efa Laela Fakhriah, Mekanisme Small Claims Court Dalam Mewujudkan Tercapainya Peradilan Sederhana, Cepat, Dan Biaya Ringan, Mimbar Hukum 25, no. 2 (2013): 258.

12 Septi Wulan Sari, Penyelesaian Sengketa Melalui Small Claim Court, Ahkam: Jurnal Hukum Islam 4, no. 2 (1 November 2016): 346, https://doi.org/10.21274/ahkam.2016.4.2.327-348.
} 
Gugatan sederhana atau small claim court banyak diminati oleh masyarakat. Data Mahkamah Agung menunjukkan bahwa pada tahun 2018 pengadilan tingkat pertama di lingkungan Peradilan Umum dan Peradilan Agama telah menyelesaikan perkara gugatan sederhana sebanyak 6.469 perkara. ${ }^{13}$ Meskipun demikian, prosedur gugatan sederhana perlu dilakukan penyederhaaan lagi. Sebab belum ada klasifikasi terhadap jenis perkara yang masuk dan tingkat kerumitan perkara yang ditangani. Penyederhanaan penyelesaian sengketa di Peradilan Agama nampaknya sangat sejalan dengan PMA Nomor 2 Tahun 2015 tentang Tata Cara Penyelesaian Gugatan Sederhana (selanjutnya disebut Perma No. 2 Tahun 2015) dan PMA Nomor 14 Tahun 2016 tentang Tata Cara Penyelesaian Perkara Ekonomi Syariah Selanjutnya disebut dengan Perma No. 14 Tahun 2016), akan tetapi Perma No. 2 Tahun 2015 hanya menjadi kewenangan pengadilan umum bukan kewenangan peradilan agama seperti yang tertuang dalam Pasal 2 yang menyatakan bahwa gugatan sederhana diperiksa oleh pengadilan dalam ruang lingkup kewenangan peradilan umum. Peraturan Mahkamah Agung ini juga menjelaskan bahwa yang memeriksa dan mengadili gugatan sederhana ini adalah dengan hakim tunggal sebagaimana bunyi Pasal 1 angka 4, sedangkan Perma No. 14 Tahun 2016 hanya terbatas pada masalah ekonomi syariah.

Apabila kita melihat isi ketentuan dari Perma No. 2 Tahun 2015, maka PERMA ini uncomptle norm, karena dikhususkan pada peradilan umum saja. sedangkan Peradilan Agama juga membutuhkan mekanisme beracara sederhana terutama untuk perkara Permohonan dan Perkara Gugatan Kecil. Perma No. 14 Tahun 2016 juga uncomptle norm karena hanya terfokus terhadap penyelesaian sengketa ekonomi syariah, padahal masih ada masalah gugatan lainnya yang juga membutuhkan mekanisme peradilan sederhana seperti kasu permohonan dan gugatan (selain sengketa ekonomi syariah) yang nilainya keuangannya kecil dan pembuktiannya mudah. Jenis perkara seperti ini seharusnya mekanisme beracaranya dengan mekanisme sederhana

Penyederhaan penyelesaian sengketa berdasarkan jenis dan tingkat kesulitan perkara, Pengkategorisasian jenis perkara ini merupakan langkah awal dalam proses pembaharuan hukum acara di Pengadilan Agama. Berangkat dari hal tersebut, pokok bahasan penulisan akan dituangkan dalam penulisan penelitian ini model Small Claim Court sebagai alternatif penyelesaian perkara di pengadilan agama untuk mewujudkan asas cepat sederhana dan biaya ringan perspektif teori keadilan John Rawls. Adapun tujuan penulisan artikel ini adalah mendeskripsikan model small claim court sebagai alternatif penyelesaian perkara di Pengadilan Agama untuk mewujudkan asas cepat sederhana dan biaya ringan perspektif teori keadilan John Rawls.

\section{Metode Penelitian}

Jenis penelitian ini adalah penelitian hukum normatif. Penelitian hukum normatif merupakan suatu proses untuk menemukan aturan hukum, prinsip-prinsip hukum maupun doktrin-doktrin hukum. ${ }^{14}$ Penelitian ini dikatan penelitian hukum normatif karena hendak mengkaji model small claim court sebagai alternatif penyelesaian perkara di pengadilan agama untuk mewujudkan asas cepat sederhana dan biaya ringan perspektif teori keadilan John Rawls. Metode pendekatan yang digunakan dalam penelitian ini adalah pendekatan perundang-undangan (statute approach), pendekatan perbandingan (comparative approach), pendekatan konseptual (conceptual approach), Setiap pendekatan yang dilakukan mempunyai korelasi terhadap hasil penelitian yang akan dilakukan. Pendekatan

\footnotetext{
${ }^{13}$ Mahkamah Agung RI, Laporan Tahunan Mahkamah Agung Tahun 2018, 140.

${ }^{14}$ Peter Mahmud Marzuki, Penelitian Hukum (Jakarta: Kencana, 2005), 35.
} 
perundang-undangan (statute approach) dilakukan dengan menelaah semua regulasi atau peraturan perundang-undangan yang bersangkut paut dengan isu hukum yang akan diteliti.

Pendekatan perbandingan (comparative approach) dilakukan dengan mengadakan studi perbandingan hukum. Melakukan perbandingan harus mengungkapkan persamaan dan perbedaan. Sedangkan Pendekatan konseptual (conceptual approach) digunakan untuk membuat konsep model baru. Konsep hukum yang dibangun dalam penelitian ini adalah model small claim court sebagai alternatif penyelesaian perkara di pengadilan agama untuk mewujudkan asas cepat sederhana dan biaya ringan perspektif teori keadilan John Rawls. Semua bahan hukum yang didapat kemudian dipilah sesuai dengan kebutuhan masing-masing. Kemudian dilakukan analisis keseluruhan aspek untuk mengetahui keterkaitan dengan isu hukum yang diteliti dengan menggunakan analisis secara induktif (khusus-umum) sehingga memberikan gambaran hasil secara utuh.

\section{Hasil dan Pembahasan Small Claim Court dan Pengkategorian Jenis Perkara}

Gugatan sederhana atau Small Claims Court mempunyai arti "a court that informally and expeditiously adjudicates claims that seek damages below a specified monetary amount, us claims to collect small accounts or debts also termed small debts court; conciliation court. " 15 Metode Small Claim Court adalah peradilan sederhana yang memiliki karakteristik seperti penyelesaian sengketa, proses peradilan ini dilakukan dengan berifat cepat dan efisien (expeditiously) dan selain tu tunutn ganti rugi dengan jmlah hitungan yang spesifik (spesific monetary amount). ${ }^{16}$

Pengadilan pada tingkat pertama harus dirancang sedemikian rupa sehingga bisa independen, berintegritas dan mampu melayani masyarakat ketika beracara di pengadilan berdasarkan asas biaya rendah, cepat dan sederhana. Melalui small claim court, penyelesaian sengketa gugatan akan diputus selambat-lambatnya 25 hari. ${ }^{17}$ Untuk memberikan pengertian terhadap perkara perdata dalam arti luas maka termasuk di dalamnya perkara-perkara perdata baik yang mengandung sengketa maupun yang tidak mengandung sengketa, sedangkan pengertian perkara perdata dalam arti yang sempit adalah perkara- perkara perdata yang di dalamnya sudah dapat dipastikan mengandung sengketa. Hal ini dikemukakan oleh Sudikno Mertokusumo ${ }^{18}$ yang menyatakan bahwa perkara perdata adalah "meliputi baik perkara yang mengandung sengekta (contentius) maupun yang tidak mengandung sengekta (voluntair)."

Setiap perkara perdata yang diajukan ke persidangan di Pengadilan Agama tidak hanya perkara yang berhubungan dengan suatu sengketa saja, akan tetapi di dalam praktiknya juga terdapat suatu penyelesaian suatu masalah dengan yurisdiksi voluntair atau permohonan penetapan hak yang tidak mengandung sengketa sebagaimana yang tercantum di dalam Pasal 5 ayat (3) a Undang-Undang Darurat Nomor 1 Tahun 1951 tentang Tindakan-Tindakan untuk Menyelenggarakan Sususnan, Kekuasaan dan Acara Pengadilan- Pengadilan Sipil). Tuntutan hak sebagaimana diuraikan diatas, dibedakan

\footnotetext{
${ }^{15}$ Bryan A. Gardner, Black's Law Dictionary, vol. VIII (St. Paul: West Publishing, 2004), 311.

16 Yance Arizona, Small Claim Court: Apa Gunanya Bagi Masyarakat Adat dan Lingkungan Hidup (Depok: Fakultas Hukum UI, 2010), 1.

17 Nevey Varida Ariani, "Gugatan Sederhana dalam Sistem Peradilan di Indonesia," Jurnal Penelitian Hukum De Jure 18, no. 3 (21 September 2018): 382, https://doi.org/10.30641/dejure.2018.V18.381-396.

${ }^{18}$ Sudikno Mertokusumo, Hukum Acara Perdata Indonesia (Yogyakarta: Liberty, 1993), 1.
} 
menjadi dua macam. Pertama, tuntutan hak yang mengandung sengketa atau disebut dengan gugatan, dimana di dalamnya terdapat sekurang- kurangnya dua pihak. Kedua, tuntutan hak yang tidak mengandung sengketa yang disebut permohononan. Jadi, baik gugatan atau permohonan bisa diselesaikan dengan small claim court, salama kriteria persidangan small claim court terpenuhi.

\section{Perkara Contentius Yang Bisa Diselesaikan Melalui Small Claim Court}

Perkara contentius ialah perkara gugatan/permohonan yang di dalamnya mengandung sengketa antara pihak-pihak. Nomor perkara contentius diberi tanda $\mathrm{G}$ misalnya Nomor: 60/Pdt.G/2016/PA.MLG. Perkara ijin ikrar talak dan poligami meskipun dengan istilah permohonan, tetapi karena mengandung sengketa maka termasuk perkara contentius dan bertanda G. ${ }^{19}$ Pada perkara contentius terdapat dua pihak atau lebih yang bersengketa. Pihak yang mengajukan gugatan disebut Penggugat, sedangkan pihak yang digugat disebut Tergugat. Apabila penggugat dan tergugat lebih dari satu orang maka disebut Penggugat I, Penggugat II, dan seterusnya. Demikian juga Tergugat I, Tergugat II, dan seterusnya. Kadang-kadang ada pula pihak-pihak yang turut Tergugat yaitu pihak yang tidak digugat langsung namun ada kemungkinan mempunyai hak dalam objek yang dipersengketakan, tetapi ia tidak mau turut menggugat. ${ }^{20}$

Di dalam gugatan harta waris atau hibah, pihak yang menguasai objek sengketa disebut Tergugat, sedangkan pihak yang tidak menguasai objek sengketa tetapi mempunyai hak dalam objek sengketa dan mau tidak mau menjadi Penggugat maka ia menjadi pihak "Turut Tergugat". Karena semua orang yang diperkirakan mempunyai hak pada objek sengketa harus menjadi pihak dalam perkara. Di samping itu, ada perkara permohonan yang di dalamnya mengandung sengketa maka pihak yang mengajukan disebut Pemohon dan pihak lawan disebut Termohon. Dalam perkara permohonan ijin ikrar talak, maka suami disebut Pemohon dan isteri disebut Termohon. ${ }^{21}$ Berangkat dari hal di atas, titik tekan perkara kontentius adalah perkara itu terdapat sengketa, jika tidak terdapat sengketa maka ia perkara voluntair. Untuk itu ini menjadi sangat penting untk membedakan perkara itu masuk perkara kontentius atau perkara volunter mengingat kewenangan pengadilan agama semakin banyak dan semakin luas. Adapun perkara kontemtius yang dapat diselesaikan dengan mekanisme Small Claim Court minimal harus memenuhi dua kriteria yaitu (1) batasan nominal tertentu dan (2) pembuktiannya mudah dan sederhana. Adapun perkara volunter mutlak menggunakan meknisme Small Claim Court.

Perkara yang dapat diselesaikan menggunakan gugatan sederhana harus memenuhi kriteria batas nominal. Untuk menentukan kriteria tersebut, setidaknya ada tiga hal yang penulis jadikan acuan, yaitu: Nisab Zakat Kadar Zakat Emas dan Perak Serta Profesi, berdasarkan kajian perbandingan dengan negara lain, serta berdasarkan Perma No. 2 Tahun 2015. Pertama, Nisab Dan Kadar Zakat Emas, Perak dan Profesi. Nishab Emas emas adalah dua puluh misqal/dinar. Dua puluh misqal itu menurut al-Qardhawi adalah $=85$ gram atau 94 gram emas murni menurut BAZIS. ${ }^{22}$ Sedangkan nisab perak

\footnotetext{
${ }^{19}$ Mukti Arto, Praktek Perkara Perdata (Yogyakarta: Pustaka Pelajar, 2003), 41.

${ }^{20}$ Arto, 42.

21 Arto, 42.

22 Jika hitungannya nisab emas yang digunakan oleh BAZIS yaitu sebesar 94 gram emas murni, jika dikoversikan dengan nilai beli emas pada hari ini berdasarkan pada laman http://harga-emas.org/ yang dikases pada hari senin, 1 Agustus 2017 pada pukul 12:05 WIB, harga beli 1 gram emas murni = Rp. 534.000, maka harga 94 gram emas murni = Rp. 50.196.000
} 
adalah 200 dirham. Menurut ulama Hanafiyyah, 200 dirham itu sama dengan kurang lebih 700 gram, atau kurang lebih 624 gram menurut jumhur ulama. Adapun kadar pungutan zakat emas dan perak adalah $1 / 40$ nya atau 2,5 persen . Dan kewajiban zakat mempunyai emas sebanyak 85 gram setelah cukup masa satu tahun ia harus mengeluarkan zakatnya sebanyak kurang lebih 2,125 gram. Demikian pula seseorang yang mempunyai oerak sebnayak 700 gram setelah cukup masa satu tahun ia harus mengeluarkan zakatnya sebanyak 17,5 gram.

Ketentuan nisab dan kadar zakat emas dan perak itu berdasarkan hadits Nabi SAW, anatra lain: Hisab shahih yang diriwayatkan dari Ali bin Abi Thalib ra. Raulullah saw bersabda yang artinya:

“Apabila kamu memiliki 200 dirham perak dan telah cukup masa setahun, maka zakatnya 5 dirham. Dan tidaklah kamu harus mengeluarkan zakat yakni pada emas, sehingga kamu memiliki 20 dinar. Maka apabila kamu telah memiliki 20 dinar dan telah cukup setahun, maka wajib dikeluarkan zakatnya $1 / 2$ dinar. $^{23}$

Kemudian Hadist Abu Sa'id al-Khudri ra, ia berkata yang artinya:

"Tidak ada kewajiban zakat pada tamar yang kurang dari 5 wasaq, dan tidak ada kewajiban zakat wariq (perak) yang kurang dari 5 auqiyyah, dan kewajiban zakat pada unta yang kurang dari 5 dzaud. ${ }^{24}$

Nisab zakat emas adalah 20 mitsqal ${ }^{25}$ atau satu dinar. ${ }^{26}$ Kira- kira, kadar seperti itu sama dengan 14 lira emas Utsmani, 12 lira Inggris, ${ }^{27}$ kira- kira sama dengan 100 gram dalam ukuran mitsqal Iraqi, atau sama dengan 96 gram ukuran mitsqal orang-orang non Arab. Menurut jumhur, ukuran emas tersebut sama dengan 91 23/25 gram. Perbedaan tersebut antara dua ukuran mitsqal (Iraqi dan non-Arab) hanya berkisar 0,2 gram. Mitsqal non-Arab sama dengan 4,8 gram, sedangkan mitsqal Iraqi sama dengan 5 gram. Kita dianjurkan untuk berpegang kepada ukuran yang lebih sedikit, sebagai upaya kehatihatian sehingga ukuran emas di atas sama dengan 96 gram atau 85 gram. Hal ini disesuaikan dengan dirham orang Arab yang 1 dirhamnya sama dengan 2, 975 gram. Nisab perak 200 dirham yang kira- kira menurut mazhab Hanafi sama dengan 700 gram atau menurut jumhur 643 gram. ${ }^{28}$ Ulama jumhur (selain mazhab syafi'i), membolehkan penggabungan kedua jenis nuqud (emas dan perak) untuk menggenapkan jumlah nisab. Dengan demikian, emas bisa digabungkan dengan perak, begitu pula sebaliknya. Atas dasar ini, orang yang memiliki 100 dirham (perak) dan 5 mitsqal (emas) yang harganya sama dengan 10 dirham, wajib mengeluarkan zakatnya sebab maksud dari zakat kedua jenis itu sama. Keduanya sama dengan satu jenis.

\footnotetext{
${ }^{23}$ Asy- Syaukani, Nailul- Autar, vol. IV (Mesir: Mustafa al-Babi al-Halabi, 1986), 138.

${ }^{24}$ Syaukani, IV:166. satu auqiyyah= 400 dirham (menurut kesepakatan ulama)

${ }^{25}$ Satu mitsqal menurut Mazhab Hanafi sama dengan lima gram, dan menurut jumhur adalah 3, 60 gram. Dan Bank Faisal di Sudan menetapkan bahwa satu mitsqal sama dengan 4, 458 gram. Ukuran inilah tampaknya yang mendekati kebenaran, yang dibulatkan menjadi 4,25 gram.

${ }^{26}$ Dapat dicatatkan di sini bahwa mazhab Hanbali bahwa satu dinar lebih kecil dari mitsqal, sehingga nisab zakat ini hitungannya menjadi $1 / 9+252 / 7$ dinar

${ }^{27}$ Satu lira Inggris sama dengan 2,50 dirham, dan stau lira Utsmani sama dengan 2,25 dirham. Sedangkan satu Prancis sama dengan 2 dirham.

28 Dua ratus dirham kalau ditimbang sama dengan 7 mitsqal, dan satu dinar sama dengan 20 qirath. Dan 1 qirath sama sengan lima syair. Sehingga satu dirham sama dengan 70 syair, dan 1 mitsqal sama dengan 100 syair. Ada kesamaan antara mitsqal dan dinar. Satu dirham menurut mazhab Hanafi sama dengan 3,0 gram, sedangkan menurut jumhur 3,208 gram. Dan I dirham Arab sama dengan 2, 975 gram.
} 
Mazhab Syafi'i berpendapat bahwa masing-masing dari kedua nuqud tersebut tidak boleh saling digabungkan, seperti halnya unta dan sapi. Satu jenis harta hanya bias digenapkan dengan jenis yang sama, kendatipun kualitasnya berbeda. Pendapat yang pertama, yakni pendapat jumhur, adalah pendapat yang wajib diikuti pada zaman sekarang sebab hal ini berkenaan dengan mata uang. Dewasa ini, penggabungan masingmasing jenis nuqud kepada jenis nuqud yang lain merupakan hal yang mesti. Penentuan harga pengeluaran nisab zakat emas dan perak disesuaikan dengan masanya, sesuai dengan daya jual yang dimiliki oleh mata uang yang berlaku. Begitu juga, penentuan tersebut disesuaikan dengan harga pengeluaran masing- masing emas dan perak pada setiap tahunnya di daerah muzakki, yakni ketika zakat tersebut hendak dikeluarkan. Harga masing- masing emas dan perak sering berubah, selalu tidak tetap, sedangkan syara' hanya membatasi kadar keduanya, yaitu emas sebanyak 20 mitsqal atau dinar dan perak sebanyak 200 dirham. Kedua jenis nuqud itu adalah satu dan mempunyai dasar penentu diyat.

Kalau nisab penghasilan pegawai dan usaha jasa ini dikembalikan kepada mal mustafad maka para sahabat dan ulama fiqih menyatakan: Wajib menzakati mal mustafad pada waktu menerimanya apabila mencapai satu nisab, maka berarti bagi pegawai, buruh yang gajinya perbulan sudah mencapai seharga 85 gram emas baru diwajibkan zakat. Mereka yang gajinya dibawah standar minimal itu tidak diwajibkan menzakati gajinya. Kalau demikian halnya maka di Indonesia tidak ada seorang pegawaipun yang kena kewajiban zakat. Akan tetapi bila hal tersebut kita kembalikan sebagaimana golongan Hanabilah bahwa untuk mencapai jumlah satu nishab dari hasil tanaman, maka penghasilan selama satu tahun diperhitungkan secara kumulatif, meskipun dari berlainan negeri dan meskipun dari satu pohon yang berbuah satu kali setahun, karena ia merupakan buah hasil satu tahun. Maka berarti gaji pegawai, upah buruh, honorarium seniman, penghasilan dokter dan lain sebagainya apabila diperhitungkan secara komulatif selama satu tahun sudah mencapai satu nishab, maka harus dikenakan zakat. Nishabnya ialah 85 gram emas murni, dengan cara ini terwujudlah keseimbanganm dan pemerataan kewajiban zakat antara kaum buruh, pegawai, pengusaha dan hokum tani. Pandangan yang kedua inilah yang dipakai oleh al- Qrdhawi, demikian juga oleh BAZIS. ${ }^{29}$

Kedua, Berdasarkan Kajian Perbandingan Small Claim Court Beberapa Negara. Sebenarnya kajian tentang ini, sudah dijelaskan di bab 3. Adapun mengenai ketentuannya akan dirangkum dalam beberapa hal berikut ini: Irlandia menggunakan SCC, tidak nominal khusus tetapi hanya berkaitan dengan gugatan yang melibatkan konsumen yang mengalami kerugian. Kemudian Amerka Serikat menggunakan SCC dengan Batasan Nominal $€ 2000$, menunjukkan $€ 1=$ Rp. 15.625, maka nilai $€ 2.000=$ Rp. 31.250.000. Sementara Canada menggunakan SCC dengan Batasan Nominal berbeda-beda di setiap provinsi. Batasan nominal terbesar \$ 50.000 yang dipakai di provinsi Alberta, dan nilai yang paling rendah adalah $\$ 10.000$ yang dipakai pada provinsi Monitoba. Jika nilai ini dikonversikan dalam jumlah rupiah berdasarkan nilai tukar rupiah pada hari ini berdasarkan pada hari senin, 1 Agustus 2017 pukul 11: $32 \mathrm{WIB}$, nilai $\$ 1=\mathrm{Rp}$. 10.675, maka nilai $\$ 50.000=$ Rp. 533.750.000, sedangkan nilai $\$ 10.000=$ Rp. 106.750.000. Kemudian Brazil menggunakan SCC dengan Batasan Nominal R\$24,880.00, jika nilai ini dikonversikan kepada nilai tukar terhadap rupiah pada hari senin, 1 Agustus 2017 pada pukul 11:45 WIB nilai $\mathrm{R} \$ 1=\mathrm{Rp} .4 .237,5$, maka nilai $\mathrm{R} \$ 24,880.00=\mathrm{Rp}$. 105.439.000. Inggris menggunakan SCC dengan Batasan Nominal £10.000, jika nilai ini dikonversikan

${ }^{29}$ Yusuf Qaradhawi, Fiqh az Zakat, vol. II (Mesir: Dar al-Irsyad, 1987), 515. 
kepada nilai tukar terhadap rupiah pada hari senin, 1 Agustus 2017, pada pukul 11:52 WIB nilai $£ 1=$ Rp. 17.475 , maka nilai $£ 10.000=$ Rp. 174.750.000. New South Wales menggunakan SCC dengan Batasan Nominal $£ 10.000$, jika nilai ini dikonversikan kepada nilai tukar terhadap rupiah pada hari senin, 1 Agustus 2017, pada pukul 11:52 WIB nilai $£ 1=$ Rp. 17.475, maka nilai $£ 10.000=$ Rp. 174.750.000, Dan Eropa menggunakan SCC dengan Batasan Nominal $€ 2.000$, jika nilai ini dikonversikan kepada nilai tukar terhadap rupiah pada hari senin, 1 Agustus 2017, pada pukul 11:58 WIB nilai $€ 1=$ Rp. 15.625, maka nilai $€ 2.000=$ Rp. 31.250.000.

Ketiga, Berdasarkan Perma No. 2 Tahun 2015. Peraturan Mahkamah Agung No. 2 Tahun 2015 tentang Penyelesaian Gugatan Sederhana (Perma No. 2 Tahun 2015) merupakan sebuah kebijakan baru dari Mahkamah Agung segai penyelenggara tertinggi kekuasaan kehakiman di Indonesia.yang harus di apresiasi sebagai upaya menciptakan prosedur penyelesaia sengketa yang lebih sederhana, cepat dan biaya rngan. Sebuah jalan baru bagi masyarakat untuk memperoleh keadilan yang selama ini mereka masih berfikir berulang kali membawa kasusnya ke pengadilan untuk mengajukan gugatan dengan alasan biaya yang mahal dan ketidakpastian lamanya persidangan.

Selama ini penerapan asas cepat, sederhana dan biaya ringan masih jauh dalam tataran implementatif. Kini dengan hadirnya Perma No. 2 Tahun 2015 telah tersedia prosedur yang lebih sederhana dan lebih cepat untuk penyelesaian gugatan. Pasal 1 angka 1 Perma No. 2 Tahun 2015 menyatakan bahwa penyelesaian gugatan sederhana tata cara pemeriksaan di persidangan terhadap gugatan perdata dengan nilai gugatan materiil paling banyak Rp. 200.000.000 (dua ratus juta rupiah) yang diselesaikan dengan tata cara dan pembuktiannya sederhana. Pasal 5 ayat (2) perma ini menyatakan bahwa penyelesaian gugatan sederhana paling lama 25 (dua puluh lima) hari sejak hari sidang pertama.

Berangkat dari bagan di atas, nilai nominal Nisab Zakat kadar emas sebesar Rp. 50.196.000 (Lima Puluh Juta seratus sembila puluh enam ribu rupiah), sedangkan nilai nominal Small Clam Court di beberapa Negara beragam, tertinggi di Provinsi Alberta Canada sebesar Rp. 533.750.000 (lima ratus tiga puluh tiga juta tujuh ratus lima puluh ribu rupiah) dan nilai nominal terendah di Amerika serikat sebesar Rp. 31.250.000 (tiga puluh satu juta dua ratus lima puluh ribu rupiah). Menurut Pasal 1 angka 1 Perma No. 2 Tahun 2015 nilai gugatan materiil paling banyak Rp. 200.000 .000 (dua ratus juta rupiah). Untuk Indonesia, batasan nominal perkara kontensius yang dapat diselesaikan melalu Small Claim Court adalah sebesar Rp. 200.000.000,00, dengan alasan bahwa nominal tersebut merupakan hasil kajian yang relevan dengan konteks Indonesia. Batasan maksimal Rp. 200.000.000 sudah cukup untuk diselesaikan dengan model Small Claim Court.

Kriteria yang kedua dalam hal penerapan Small Claim Court di Pengadilan Agama adalah proses pembuktiannya mudah dan sederhana. Apabila dalam sebuah kasus yang terdapat di Pengadilan Agama, proses pembuktiannya mudah dan Sederhana, maka proses beracaranya menggunakan model Small Claim Court. Sebagai bahan perbandingan, dalam hukum acara pidana, proses pemeriksaan di persidangan dibagi menjadi tiga, yaitu acara pemeriksaan biasa, singkat dan cepat (tindak pidana ringan dan perkara lalu lintas). Pembeda diantara ketiganya adalah untuk acara cepat hanya perkara yang diancam dengan pidana penjara atau kurungan paling lama tiga bulan atau denda sebanyak-banyaknya tujuh ribu lima ratus rupiah dan penghinaan ringan. Diluar hal yang disebutkan dalam Pasal 205 KUHAP tersebut maka tidak dapat diperiksa secara cepat. Pilihannya adalah acara pemeriksaan biasa atau singkat. Penentuan apakah dengan acara 
biasa atau singkat ada di tangan penuntut umum, dengan melihat pada pembuktian dan penerapan hukumnya mudah dan sifatnya sederhana. Penjelasan Pasal 203 KUHAP tersebut tidak memberikan ukuran mudah pembuktian dan penerapan hukum yang sederhana.

Pada penerapannya acara pemeriksaan biasa dan singkat mempunyai perbedaan yang signifikan, salah satunya apabila dilihat dari rangkaian proses persidangan yang harus dilakukan. Dalam praktek, untuk persidangan perkara pidana yang dilakukan dengan acara pemeriksaan biasa maka untuk pembacaan dakwaan (tanpa ada eksepsi), pembuktian, tuntutan dan putusan, setidaknya akan memerlukan empat kali persidangan, jika setiap penundaan persidangan selama satu minggu maka memerlukan waktu satu bulan untuk menyelesaikannya. Sedangkan apabila diajukan secara singkat maka dalam satu kali persidangan dapat diselesaikan sampai dengan putusan. Pada hukum acara tata usaha negara, juga dikenal proses pemeriksaan acara biasa, cepat dan singkat. Philipus M. Hadjon ${ }^{30}$ menjelaskan bahwa pemeriksaan dengan acara biasa diawali dengan pemeriksaan persiapan. Pengadilan memeriksa dan memutus sengketa dengan 3 (tiga) orang hakim, hal ini sesuai dengan ketentuan Pasal 68 ayat (1) UU No. 5 Tahun 1986 tentang Peradilan Tata Usaha Negara.

Pemeriksaan dengan acara cepat dilakukan apabila terdapat kepentingan penggugat yang cukup mendesak yang harus dapat disimpulkan dari alasan-alasan permohonannya, penggugat dalam gugatannya dapat memohon kepada Pengadilan supaya pemeriksaan sengketa dipercepat. ${ }^{31}$ Pemeriksaan dengan acara cepat dilakukan dengan Hakim Tunggal. ${ }^{32}$ Ketua Pengadilan dalam jangka waktu 14 (empat belas) hari setelah diterimanya permohonan pemeriksaan acara cepat, mengeluarkan penetapan tentang dikabulkan atau tidak dikabulkannya permohonan tersebut. Terhadap penetapan tersebut tidak dapat digunakan upaya hukum. Untuk hal permohonan pemeriksaan dengan acara cepat dikabulkan, Ketua Pengadilan dalam jangka waktu 7 (tujuh) hari setelah dikeluarkannya penetapan menentukan hari, tempat, dan waktu sidang tanpa melalui prosedur pemeriksaan persiapan. Tenggang waktu untuk jawaban dan pembuktian bagi kedua belah pihak, masing-masing ditentukan tidak melebihi 14 (empat belas) hari.

Pemeriksaan dengan acara singkat dilakukan terhadap perlawanan. Perlawanan tersebut diajukan terhadap penetapan dari prosedur semisal dalam tenggang waktu 14 (empat belas) hari setelah penetapan diucapkan. ${ }^{33}$ Pemeriksaan singkat dilakukan karena adanya perlawanan penggugat tentang gugatannya yang tidak diterima atau tidak berdasar. Dalam hal perlawanan tersebut dibenarkan oleh Pengadilan, maka penetapan tersebut gugur demi hukum dan pokok gugatan akan diperiksa, diputus dan diselesaikan menurut acara biasa. Terhadap putusan mengenai perlawanan itu tidak dapat digunakan upaya hukum. Berangkat dari hal di atas, seharusnya di dalam proses beracara dalam hukum perdata, harus juga bisa disidangkan dengan cara cepat dan singkat. Pada hukum acara pengadilan agama, hanya dikenal acara biasa. Pemeriksaan dengan acara cepat dan singkat pada pengadilan agama itu dapat diwujudkan dengan menggunakan Small Claim Court atau mekanisme penyelesaian gugatan sederhana.

Beberapa hal di bawah ini dapat menunjukkan bahwa pembuktian mudah dan penerapan hukum sederhana pada peradilan agama yaitu: Pertama, adalah keterangan

\footnotetext{
${ }^{30}$ Philipus Hadjon M., Pengantar Hukum Administrasi Indonesia (Yogyakarta: Gadjah Mada University Press, 2011), 331.

${ }^{31}$ Pasal 68 s.d. Pasal 97 UU No. 5 Tahun 1986

${ }^{32}$ Pasal 98 ayat (1) UU No.5 Tahun 1986

${ }^{33}$ Pasal 62 ayat (3) huruf a UU No. 5 Tahun 1986
} 
tergugat yang membenarkan gugatan sepenuhnya. Meski keterangan tergugat hanya sebagai salah satu alat bukti dan pengakuan tergugat dapat dijadikan dasar bahwa proses pembuktiannya itu mudah dan sederhana. Kedua, perkara perdata yang menjadi kewenangan Pengadilan Agama adalah perkara Volunter. Untuk itu, peradilan agama dapat menerapkan konsep Small Claim Court terhadap semua perkara yang masuk khususnya perkara kontensius, tentu sebelum menggunakan mekanisme Small Claim Court, ada kriteria tertentu yang harus dipenuhi yaitu nilai batasan nominal dan pembuktiannya mudah dan sederhana. Perkara yang masuk ke Pengadilan Agama di proses sesuai dengan prosedur yang ada, barulah sebelum persidangan pertama (tentunya setelah melalui proses mediasi), hakim bisa menilai bahwa perkara itu disidangkan dengan acara biasa atau menggunakan Konsep Small Claim Court. Jadi kewenangan menilai sebuah perkara itu diperiksa dengan acara biasa atau Small Claim Court terletak pada penilaian ketua Pengadilan Agama.

\section{Model Small Claim Court Sebagai Alternatif Penyelesaian Perkara Di Pengadilan Agama Perspektif Teori Keadilan John Rawls}

Peradilan Agama berdiri selain karena faktor kompleksitas nilai kehidupan masyarakat yang menyentuh secara langsung atau tidak langsung yang terkait dengan nilai-nilai hukum, moral dan etika Islam, juga karena kebutuhan masyarakat dan bangsa Indonesia yang beragama Islam. Untuk itu, diperlukan adanya keseimbangan dalam penerapan hukum Islam kepada umat Islam di Indonesia, baik dari segi asubtansi hukum maupun dari segi lembaga yang menanganinya. Sehubungan dengan kedua hal tersebut, Peradilan Agama melaksanakan tugas-tugas peradilan dengan menerapkan hukum Islam dalam menyelesaikan perkara yang diajukan kepadanya berdasarkan pertimbangan nilainilai hukum Islam dan cita-cita batin umat Islam. Keberadaan Peradilan Agama dalam wilayah Negara Republik Indonesia telah tumbuh dan berkembang atas kehendak bangsa Indonesia sejak sebelum pemerintahan kolinial terumata bangsa Belanda menginjakkan kakinya di bumi Nusantara. Dalam lintas perpolitikan baik di masa pemerintahan Kolonial Belanda maupun di Pemerintahan Negara Republik Indonesia, Peradilan Agama selalu mengalami tekanan.

Misalnya di masa Pemerintahan Kolinial Belanda kewenangan peradilan agama untuk daerah Jawa dan Madura berdasarkan Stablat (Stbl) 1882 No. 152 jo Stbl. 1937 No. 116 dibatasi hanya memeriksa perkara perkawinan. Usaha untuk mengkerdilkan berlakunya hukum Islam melalui Stbl 1937 No. 116 tersebut sangat dipengaruhi oleh pandangan politisi dan akademik Belanda bahwa masalah perkawinan dan warisan adalah masalah negara. Karena itu agama Islam dapat dipandang sebagai negara dalam negara. Pada perkembangannya, kasus-kasus yang masuk ke Pengadilan Agama tiap tahun mengalami peningkatan dan akibatnya terjadi penumpukan perkara yang hampir ribuan tiap tahunnya. ${ }^{34}$ Berikut ini data perkara di Pengadilan Agama Kabupaten Malang tahun 2017.

Tabel 1. Statistik Perkara di Pengadilan Agama Kab Malang Tahun 2017.

\begin{tabular}{llcccccc}
\hline No & Bulan & $\begin{array}{c}\text { Sisa bulan } \\
\text { lalu }\end{array}$ & $\begin{array}{c}\text { Perkara } \\
\text { Masuk }\end{array}$ & Putus & Minutasi & $\begin{array}{c}\text { Belum } \\
\text { minutasi }\end{array}$ & Sisa \\
\hline 1 & Januari & 1401 & 742 & 817 & 765 & 0 & 1326 \\
\hline
\end{tabular}

\footnotetext{
${ }^{34}$ Berdasarkan data Pengadilan Agama Kabupaten Malang Tahun 2017
} 
Erfaniah Zuhriah dan Miftahuddin Azmi, Model Small Claim Court... | 139

\begin{tabular}{|c|c|c|c|c|c|c|c|}
\hline 2 & Februari & 1326 & 632 & 594 & 588 & 0 & 1374 \\
\hline 3 & Maret & 1374 & 710 & 705 & 705 & 0 & 1379 \\
\hline 4 & April & 1379 & 623 & 652 & 650 & 0 & 1350 \\
\hline 5 & Mei & 1350 & 605 & 721 & 697 & 0 & 1234 \\
\hline 6 & Juni & 1234 & 285 & 500 & 500 & 0 & 1019 \\
\hline 7 & Juli & 1019 & 912 & 458 & 438 & 0 & 1473 \\
\hline 8 & Agustus & 1473 & 873 & 868 & 848 & 0 & 1478 \\
\hline 9 & September & 1478 & 837 & 746 & 745 & 0 & 1569 \\
\hline 10 & Oktober & 1569 & 772 & 865 & 819 & 0 & 1476 \\
\hline 11 & November & 1476 & 793 & 775 & 746 & 0 & 1492 \\
\hline 12 & Desember & 1492 & 559 & 682 & 682 & 0 & 1369 \\
\hline
\end{tabular}

Untuk itu perlu dilakukan sebuah terobosan hukum untuk mengurai dan mempercepat proses persidangan, dan penulis menawarkan konsep Small Claim Court sebagai mekanismes penyelesaian gugatan sederhana. Mengenai Model Small Claim Court sebagai alternatif penyelesaian perkara di Pengadilan Agama, saya akan mengkajinya dalam perspektif Teori Keadilan John Rawls.

John Rawls mengemukakan bahwa kesukarelaan segenap anggota masyarakat untuk menerima dan mematuhi ketentuan-ketentuan sosial yang ada hanya dimungkinkan jika masyarakatnya tertata baik di mana keadilan sebagai fariness menjadi dasar bagi prinsip-prinsip pengaturan institusi-institusi yang ada di dalamnya. ${ }^{35}$ Ketika berbicara tentang ketentutan-ketentuan sosial yang mengatur kehidupan bersama, Rawls sebenarnya sedang menekankan upaya untuk merumuskan prinsip-prinsip yang mengatur distribusi hak dan kewajiban di antara segenap anggota suatu masyarakat. Penekanan terhadap masalah hak dan kewajiban, yang didasarkan pada suatu konsep keadilan bagi suatu kerja sama sosial, menunjukan bahwa teori keadilan Rawls memusatkan perhatian pada bagaimana mendistribusikan hak dan kewajiban secara seimbang di dalam masyarakat sehingga setiap orang berpeluang memperoleh manfaat darinya dan secara nyata, serta menanggung beban yang sama.

John Rawls merumuskan kedua prinsip keadilan sebagai berikut: ${ }^{36}$ Pertama, Setiap orang harus memiliki hak yang sama atas kebebasan dasar yang paling luas, seluas kebebasan yang sama bagi semua orang. Kedua, Ketidaksamaan sosial ekonomi harus diatur sedemikian rupa sehingga diharapkan memberi keuntungan bagi bagi orang-orang yang paling tidak beruntung dan semua posisi dan jabatan terbuka bagi semua orang. Penerapan Teori Keadilan John Rawls dalam perumusan model Small Claim Court sebagai alternatif penyelesaian perkara di Pengadilan Agama untuk mewujudkan asas cepat sederhana dan biaya ringan bertumpu pada pendistribusi hak dan kewajiban, artinya bahwa perkara yang masuk ke pengadilan agama harus dibedakan proses beracaranya antara perkara Voluntair dan perkara Contentius karena pada hakekatnya kedua perkara diatas berbeda sehingga berbeda pula proses acaranya. Pendistribusian hak dan kewajiban ini harus seimbang berdasarkan kategori jenis perkara.

Khusus pada perkara contentius, untuk bisa menggunakan model Small Claim Court sebagai mekanisme beracara Pengadilan Agama, harus memenuhi dua kriteria yaitu (1) batasan nominal tertentu dan (2) pembuktiannya mudah dan sederhana. Hal ini relevan dengan teori Keadilan Jonh Rawls, bahwa hak dan kewajiban dalam

\footnotetext{
${ }^{35}$ John Rawls, A Theory of Justice (London: Oxford University Press, 1971), 45.

${ }^{36}$ Rawls, 60.
} 
menyelesaikan perkara tertentu di Pengadilan Agama harus seimbang berdasarkan batasan nominal tertentu dan pembuktiannya mudah dan sederhana, sehingga memberikan kepuasan kepada para pihak pencari keadilan. Small Claim Court memiliki manfaat yang sangat banyak apabila diterapkan di Pengadilan Agama, diantaranya adalah: ${ }^{37}$ Pertama, meningkatkan aksesibilitas bagi masyarakat untuk mencapai keadilan bagi masyarakat yang tidak mampu, penyelesaian kasus-kasus keseharian yang tidak kompleks, penyederhanaan prosedur menguntungkan orang awam/hukum, menekan kemungkinan perkara yang berlarut-larut, mendorong kepercayaan masyarakat kepada lembaga peradilan karena sifat peradilan yang efisien dan efektif.

Kedua, Mendorong terwujudnya azas peradilan yang sederhana, Prosedur yang lebih sederhana, Pemeriksaan oleh hakim tunggal, Selaras dengan azas "doelmatigheid" (kepatutan) karena menghindari prosedur yang berbelit-belit. Serta terwujudnya azas peradilan yang cepat, memberi kesempatan untuk memilih mekanisme dan yurisdiksi yang sah dan tepat, serta mengurangi kemungkinan penumpukkan perkara di MA dan PTA. Tentu tidak semua perkara yang masuk ke Pengadialan Agama diselesaikan melalui konsep Small Claim Court, akan tetapi ada kriteria-kriteria tertentu yang wajib dipenuhi untuk perkara kontentius sehingga bisa diselesaikan dengan menggunakan Small Claim Court. Kriterianya yaitu batasan nilai nominal tertentu yakni maksimal Rp. 200.000.000 atau pembuktiannya sederhana dan mudah. Kriteria ini bersifat alternatif artinya salah satu terpenuhi maka bisa menggunakan Small Claim Court sebagai mekanisme penyelesaian masalah dengan konsep penyelesaian gugatan sederhana. Perbedannya pada di tahapan persidangan. Sementara untuk perkara Voluntair otomatis langsung menggunakan Small Claim Court karena di dalamnya tidak ada sengketa.

Ada beberapa poin penting penggunaan Konsep Small Claim Court di Pengadilan Agama, yaitu: untuk perkara voluntair, dari awal pengajuan permohonan akan langsung di proses menggunakan konsep Small Claim Court, sampai dengan adanya penetapan pengadilan. Sementara untuk perkara contentius, ada beberapa tahapan yaitu: Pertama, Apabila memenuhi kriteria berupa Nilai Nominal di bawah Rp. 200.000.000, maka sejak awal pendaftaran gugatan, bisa langsung menggunakan konsep Small Claim Court, sampai dikelurkannya putusan pengadilan. Kedua, Apabila pembuktiannya dinilai oleh Ketua Pengadilan Agama, mudah dan sederhana, maka konsep Small Claim Court bisa digunakan, akan tetapi penilaian kriteria ini dapat ditentukan pada saat proses mediasi dan pemeriksaan pendahuluan, tentunya sebelum sidang pertama di mulai. Pada saat berjalannya waktu proses pembuktiannya sulit, maka dikembalikan lagi menggunakan acara biasa.

Oleh sebab itu, hanya ketua Pengadilan Agama yang dapat menilai bahwa pembuktian sebuah kasus mudah dan sederhana; kemudian hakim yang memeriksa adalah hakim tunggal; upaya perdamaian tetap diberikan (mediasi); prosesnya dimulai dari pembacaan gugatan, jawaban gugatan, pembuktian dan putusan; upaya hukum berupa pengajuan keberatan, adapun putusan keberatan berkekuatan hukum tetap sejak disampaikannya pemberitahuan, dan putusan keberatan tidak dapat diajukan banding, kasasi dan peninjauan kembali. Perlu ditegaskan kembali bahwa, penggunaan Small Claim Court di Pengadilan Agama adalah sebuah langka terobosan hukum dalam rangka mewujudkan asas cepat, sederhana dan biaya ringan. Konsep Small Claim Court ini sudah banyak digunakan di beberapa negara dalam rangka untuk menyelesaikan gugatan sederhana dengan nominal tertentu.

\footnotetext{
${ }^{37}$ Jamirun, "Pembahasan Small Claim Court Dalam Rancangan Hukum Acara Perdata" (Asosiasi Advokat Indonesia, Jakarta, 2013), 2-8.
} 
Ada beberapa keuntungan diterapkannya konsep Small Claim Court ini di Pengadilan Agama, yakni sebagai berikut: Pertama, Perkara gugatan perdata dengan nilai gugatannya relatif kecil. Kedua, Perbedaan proses hukum acara antara perkara dan perkara contentius. Ketiga, Perbedaan biaya perkara antara perkara voluntair dan perkara contentius. Keempat, Gugatannya langsung diajukan oleh masyarakat pencari keadilan tanpa bantuan pengacara. Kelima, Proses peradilan akan berjalan dengan cepat dan singkat, sehingga dapat memangkas waktu lamanya persidangan. Keenam, Proses administrasi perkara yang mudah serta pembuktian yang sederhana. Ketujuh, menumbuhkan kepercayaan masyarakat terhadap lembaga peradilan. Penerapan konsep Small Clim Court belum memiliki payung hukum yang jelas, sehingga harus ada pembuat upaya yang dilakukan agar pembuat kebijakan segera mungkin membuat regulasi baru sebagai payung hukum keberadaan Small Claim Court sebagai mekanisme penyelesaian sengketa di Pengadilan Agama, karena banya keuntungan yang diperolehnya.

\section{Kesimpulan}

Berdasarkan penelitian di atas, penyelesaian perkara di Pengadilan Agama melalui model small claim court merupakan terobosan baru guna menjawab dan menyelesaikan penumpukan perkara di Pengadilan tingkat pertama (baca: Pengadilan Agama). Selama ini penerapan small claim court hanya dilakukan di Pengadilan Negeri. Model small claim court dengan persepktif teori keadilan John Rawls adalah sebuah model mekanisme pembaharuan beracara di Pengadilan Agama yang bertumpu pada pendistribusian hak dan kewajiban, artinya bahwa perkara yang masuk ke Pengadilan Agama harus dibedakan proses beracaranya antara perkara voluntair dan perkara contentius karena pada hakekatnya kedua perkara diatas berbeda sehingga berbeda pula proses acaranya. Pendistribusian hak dan kewajiban ini harus seimbang berdasarkan kategori jenis perkara. Selain itu, small claim court harus berpedoaman pada Peraturan Mahkamah Agung (PERMA) Nomor 2 Tahun 2015 tentang Tata Cara Penyelesaian Gugatan Sederhana. Dengan menerapkan model small claim court perkara di peradilan agama dapat diputus sesuai dengan asas cepat, sederhana dan biaya ringan.

\section{Daftar Pustaka}

A. Gardner, Bryan. Black's Law Dictionary. Vol. VIII. St. Paul: West Publishing, 2004. Afriana, Anita, dan Isis Ikhwansyah. "Questioning the Small-Claims Court in Indonesia in the Framework of National Civil Procedural Law Reform." Jurnal Dinamika Hukum 16, no. 3 (2016): 266-72. https://doi.org/10.20884/1.jdh.2016.16.3.580.

Amdani, Yusi. "Konsep Restorative Justice Dalam Penyelesaian Perkara Tindak Pidana Pencurian Oleh Anak Berbasis Hukum Islam Dan Adat Aceh." al- 'adalah XIII, no. 1 (2016): 16.

Ariani, Nevey Varida. “Gugatan Sederhana dalam Sistem Peradilan di Indonesia.” Jurnal Penelitian Hukum De Jure 18, no. 3 (21 September 2018): 381. https://doi.org/10.30641/dejure.2018.V18.381-396.

Arizona, Yance. "Small Claim Court: Apa Gunanya Bagi Masyarakat Adat dan Lingkungan Hidup.” Depok: Fakultas Hukum UI, 2010.

Arto, Mukti. Praktek Perkara Perdata. Yogyakarta: Pustaka Pelajar, 2003.

Bodiroga, Nikola. "Some problems concerning the application of special procedural rules for small claims litigations." Zbornik radova Pravnog fakulteta, Novi Sad 49, no. 2 (2015): 653-70. https://doi.org/10.5937/zrpfns49-9137. 
Cahyani, Andi Intan. "Peradilan Agama Sebagai Penegak Hukum Islam Di Indonesia." Jurnal Al-Qadau: Peradilan Dan Hukum Keluarga Islam 6, no. 1 (30 Juni 2019): 119-32. https://doi.org/10.24252/al-qadau.v6i1.9483.

Fakhriah, Efa Laela. "Mekanisme small claims Court dalam Mewujudkan Tercapainya Peradilan Sederhana, Cepat, dan Biaya Ringan." Mimbar Hukum 25, no. 2 (2013): 13.

Fu, Yulin. "Small Claim and Summary Procedure In China." Brics Law Journal 1 (2014), no. 1 (2014): 67-81. https://doi.org/10.21684/2412-2343-2014-1-1-67-81.

Hadjon, Philipus, M. Pengantar Hukum Administrasi Indonesia. Yogyakarta: Gadjah Mada University Press, 2011.

Harahap, Yahya. Kedudukan Kewenangan Dan Acara Peradilan Agama Berdasarkan Undang-Undang No. 7 Tahun 1989. Jakarta: PT. Garuda Metropolitan Press, 1993.

Ibrahim, Malik. "Tunggakan Perkara Di Lingkungan Peradilan Agama Dan Upaya Penanggulangannya.” Aplikasia: Jurnal Aplikasi Ilmu-Ilmu Agama 18, no. 1 (30 Januari 2018): 33-50.

Iskandar, Mizaj, dan Liza Agustina. "Penerapan Asas Peradilan Sederhana, Cepat dan Biaya Ringan dalam Kumulasi Cerai Gugat dan Harta Bersama di Mahkamah Syar'iyah Banda Aceh." SAMARAH: Jurnal Hukum Keluarga dan Hukum Islam 3, no. 1 (9 Agustus 2019): 241-65. https://doi.org/10.22373/sjhk.v3i1.4403.

Jamirun. "Pembahasan Small Claim Court Dalam Rancangan Hukum Acara Perdata." Jakarta, 2013.

Mahkamah Agung RI. Laporan Tahunan Mahkamah Agung Republik Indonesia Tahun 2018: Era Baru Peradilan Modern Berbasis Teknologi Informasi. Jakarta: Mahkamah Agung, 2019.

Marzuki, Peter Mahmud. Penelitian Hukum. Jakarta: Kencana, 2005.

Mertokusumo, Sudikno. Hukum Acara Perdata Indonesia. Yogyakarta: Liberty, 1993.

Qaradhawi, Yusuf. Fiqh az Zakat. Vol. II. Mesir: Dar al-Irsyad, 1987.

Rawls, John. A Theory of Justice. London: Oxford University Press, 1971.

Sari, Septi Wulan. "Penyelesaian Sengketa Melalui Small Claim Court." Ahkam: Jurnal Hukum Islam 4, no. 2 (1 November 2016): 327-48. https://doi.org/10.21274/ahkam.2016.4.2.327-348.

Syaukani, Asy-. Nailul- Autar. Vol. IV. Mesir: Mustafa al-Babi al-Halabi, 1986.

Yaqin, Muharrom Ainul. "Konsep Small Claim Procedure Untuk Menyelesaikan Perkara Perdata Permohonan (Volunter) Di Pengadilan Agama." JURISDICTIE 6, no. 1 (2015): 37-49. https://doi.org/10.18860/j.v6i1.4088. 